\title{
Comparing successful and less successful new innovative businesses
}

\author{
Arnold PICOT, UIf LAUB and Dietram SCHNEIDER \\ Institut für Organisation, Ludwig-Maximilians-Universität München, Ludwigstrasse 28, D-8000 München 22, \\ Federal Republic of Germany
}

\begin{abstract}
This contribution offers a conceptual framework for the analysis of innovative business start-ups. This framework mainly draws on transaction cost theory. On basis of a broad empirical study of 52 hightech business start-ups in Germany the fruitfulness of the transaction cost approach with respect to research on innovation is demonstrated. Transaction cost theory gives valuable hints for the interpretation of the personal role of the entrepreneur as well as for the economic evaluation of the entrepreneurial idea. Special importance refers to the results on the organization of market transactions as a decisive determinant of economic success of innovative business start-ups.
\end{abstract}

Keywords: Innovation, organization, economics, decision theory

\section{Introduction}

Research on innovative business start-ups shows a lack of theoretical underpinning and empirical evidence (see Van de Ven, 1986, pp.590-591, and Sandberg, 1986, pp.5-7) on factors which might influence successful corporate development. This paper tries to make a contribution in order to reduce this shortcoming by presenting a new theoretical concept of entrepreneurial activities and an empirical investigation of 52 innovative business start-ups.

\section{Theoretical background}

The theoretical basis for our research is drawn from the transaction cost approach. Transaction costs are costs that have to be taken into account in order to reach an equitable exchange of goods and services in the economy or within an organization. Transaction costs mainly arise as a result of problems of information and communication between the actors involved. In a competitive

Received October 1989 world, superior forms of coordination and organization of economic activity generate the lowest transaction costs. From this point of view the theoretical background of transaction costs (see Coase, 1937; Williamson, 1975, 1985; Picot, 1982) led to an analytical framework which makes it possible to integrate different questions of research in a success-oriented concept.

This concept is based on an analysis consisting of three parts:

(1) The characteristics of innovative ideas in the market context.

(2) The necessary entrepreneurial abilities of innovative founders.

(3) The organization of the innovative start-ups in the market context.

\subsection{Innovative ideas to start a business}

In principle, an innovative entrepreneurial idea can aim at reduction of production costs (e.g., automation in manufacturing) as well as a reduction of transaction costs (e.g., new forms of organization, new ways of communicating with the market). However, it is not always possible to distinguish whether a successful innovative idea 


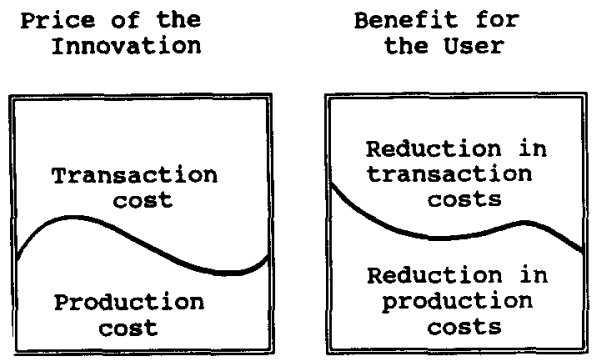

Figure 1. Price-benefit relation from the point of view of producer and user

reduces transaction costs or production costs or both. It might be the case, for example, that an innovation in the organization of marketing enables (for the first time) the procurement of certain inputs that had been left unused so far because of prohibitively high transaction costs. This transaction cost-reducing innovation leads at the same time to lower production costs in those processes which make use of those input resources. On the other hand, it happens quite frequently that process innovations in industrial production reduce uncertainties of product quality. This improvement of the physical production process results quite often also in a reduction of transaction costs, especially monitoring costs. Thus, an evaluation of innovative entrepreneurial ideas must take into account changes in production costs as well as in transaction costs on both sides (Figure 1): namely, that of the producer and that of the user of the product. From this perspective an innovative idea for a new business start-up seems only viable if, in the long run, the sum of the transaction costs and production costs per unit on the side of the entrepreneur is not higher than the perceived benefit of the user. The user benefits from using the innovative product comprises reductions in transaction costs and/or production costs in his or her domain.

An assessment of the economic viability of innovative entrepreneurial ideas must be based on the total costs without neglecting one of the two categories. However, in many cases the relevance of transaction costs is underestimated (see Picot, 1986, p.4; Picot and Schneider, 1988; pp.29-31).

\subsection{Entrepreneurial functions required for innova- tive business}

Disequilibria in markets are caused by market imperfections, especially by unequal distribution of information and knowledge, poor transparency of market conditions, insufficient knowledge about the use of products and/or modes of organization. In a dynamic world such deficiencies offer opportunities for entrepreneurial activity. In this context, entrepreneurial action can be analyzed on three levels:

(a) The innovative entrepreneur can act as an arbitrageur of information. He collects and combines pieces of knowledge and channels this knowledge to those who could use it. Information transfer between a large number of potential senders and receivers is thereby substituted. Entrepreneurial coordination of information is especially relevant for the generation of new ideas and innovative knowledge. In this way, information advantages in a dynamic competitive process can be acquired (for example, see Kirzner, 1973, pp.123; Ricketts, 1987, p.19). Entrepreneurial invention and coordination of information are similar functions.

(b) Entrepreneurial coordination of resources is especially relevant during the realization of innovative ideas. A new combination of resources as a consequence of a new entrepreneurial idea implies particular requirements for the innovator. Detecting adequate suppliers, negotiating efficient contracts and organizing internal activities have to be managed with regard to transaction costs (furthermore, the flexibility necessary for a new combination must be available. The property rights system plays a key function in this respect; see Witt, 1987; Picot and Schneider, 1988). The entrepreneurial coordination of resources for innovative ideas corresponds with the function of an organizer.

(c) The function of the market arbitrageur is the third entrepreneurial ability to be fulfilled by innovative business start-ups. Within the marketing function of the new firm the innovator has to initiate new markets, to bridge latent demand and potential supply and, thereby, to increase the transparency of the market (for example, see Wegehenkel, 1981, pp.31-41; Casson, 1982, pp.60-74; Reekie, 1984, pp.85-89). Thus the innovator reduces transaction costs in marketing and supports the diffusion of innovation (although there have been no previous investigations into the subject, it should not be overlooked that the various diffusion theories can be given a transaction cost basis). The innovative entrepreneurial func- 
Table 1

Innovation process and entrepreneurship

\begin{tabular}{ll}
\hline Type of entrepreneur & Phase of the innovation process \\
\hline Information coordinator & Invention \\
Resource coordinator & Transformation \\
Market coordinator & Diffusion \\
\hline
\end{tabular}

tion of market arbitrage serves as a 'market opener'.

The three analytically differentiated abilities of entrepreneurial innovators show that a sucessful business start-up demands a rather heterogeneous bundle of entrepreneurial functions. The three types can be paralleled with the phases of the innovation process (see Table 1; for phases of the innovation process, see Rogers, 1983, pp.135-149; Thom, 1980, pp.45-53).

\subsection{Organization of innovative businesses}

A major problem for every newly founded business is the decision between make or buy. This decision influences the degree of vertical integration of the new firm and, thereby, its size. Transaction costs play a major role in this decision (see Williamson, 1975; Picot, 1982). The level of transaction costs is determined by information problems that have to be resolved in order to come to an acceptable agreement and by the institutional form of contracting.

For a successfull start-up in a competitive world it can be useful to select the contractual mode with the lowest level of transaction costs. If information problems are low, a short-term, marketoriented form of contracting is superior. If very difficult information problems have to be overcome, a more long-term oriented, hierarchical mode of coordination will be efficient. The intensity of information problems increases with the specificity, complexity, uncertainty and indefinability of the product or service that has to be evaluated and monitored by the parties involved. In case of high information problems a more long-term oriented, integrated form of contracting is better suited to cope with these problems. This is the case as mutual risks of the parties are reduced by long-term commitments and the possibility of adjustment within a contractual framework. Particulary innovative entrepreneurial activities involve high uncertainty and severe informa- tion problems for the handling of many necessary transactions. At the same time, new entrepreneurs have a limited production capacity, as well as a limited capacity for the management of information processing. Therefore, successful innovative founders must seek to delegate management problems to the market to an extent that minimizes their transaction costs. This means that they have to look for very sophisticated modes of contracting with their suppliers. In this way, they can concentrate their limited capacities on those specific tasks that build the core of the innovative idea and that cannot be delegated to market supply.

\section{Research questions and methodology}

It can be seen that transaction costs considerations play a major role in the evaluation of innovative ideas, in the specification of entrepreneurial functions, and in the design of the internal and external organization of the start-up firm.

Thus, these three factors are the central determinants of the economic viability of innovative new businesses. From this the following research questions can be derived for the empirical investigation:

1. What influences the success of innovative ideas in the market context?

2. Is it fruitful to distinguish between the three abilities of innovative entrepreneurs (coordination of information, of resources and of markets), and what combination of such functions influence the success of the start-up firm?

3a. To what extent is the success of innovative business start-ups influenced by make-or-buy decisions, as well as by different forms of contracting?

3b. What is the influence of the organization of sales and marketing on the success of an innovative new firm?

At first, a series of twelve expert interviews with the management of venture capital companies, and other experienced practitioners, showed that our theoretical concept was accepted and supported. Furthermore, it was possible to obtain access to newly founded innovative businesses. At the same time this kind of access to the field was designed to ensure that the researchers really dealt 
Table 2

Characteristics of the sample of innovative new firms used in the present investigation; $n=52$

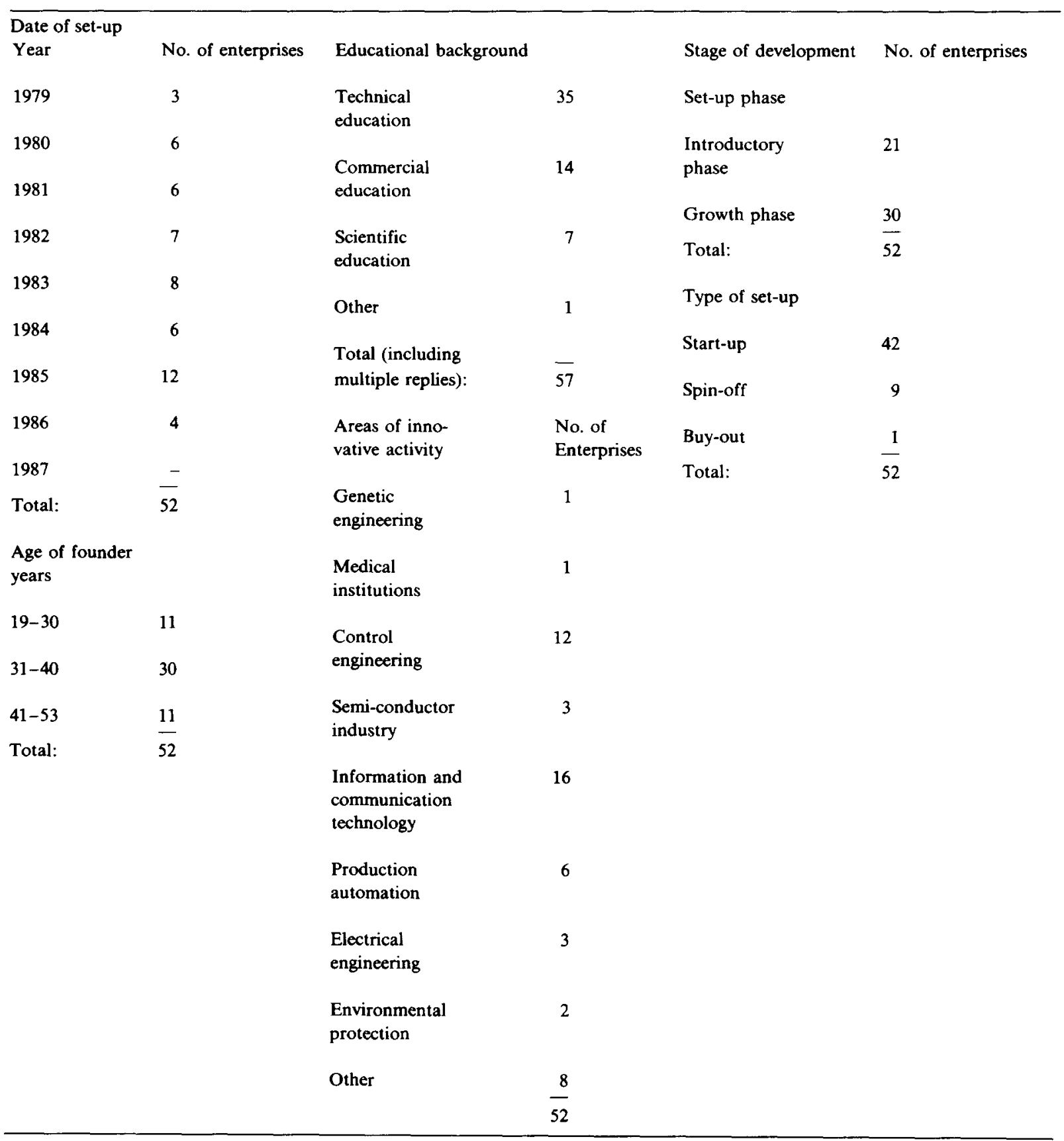

with innovative business foundations in contrast to ordinary start-ups. Thus there was no need to explicitly operationalize and examine the difficult concept of innovation.
The second step (conducted during the summer of 1987) involved interviews with 52 innovative entrepreneurs based in the Federal Republic of Germany and in Berlin. Interviewees were either 
the founders themselves or, in the case of a team foundation, the principal founder. Interviews lasted two to three hours and were guided by a structured questionnaire (including open and closed questions). Table 2 shows the main characteristics of the sample.

A main objective of the investigation was to find out whether the economic theory of transaction costs can explain the success of innovative business start-ups. Thus it was necessary to assess the economic success of the investigated new firms. As all 52 new businesses were still operating in the market, they all can be regarded as successful. As it was not possible for us to gain access to failures, we had to see whether the degree of success within this group could be explained by the theoretical framework.

Therefore, we separated the sample into a group of very successful new firms and a group of less successful new firms. For various reasons measuring the success of a new innovative firm is difficult. Therefore we applied ten different success indicators that could be derived from the empirical data:

(1) Time span between year of start-up and first year of profit.

(2) Offers for buying shares or for take-over.

(3) Average sales per employee and year.

(4) Average increase in sales.

(5) Cumulative percentage increase of sales.

(6) Cumulative percentage increase in number of employees.

(7) Volume of orders not yet processed.

(8) Cumulative percentage sales increase within the first three years of business.

(9) Average percentage increase in number of employees.

(10) Sales value in the first year of business.

This mix of indicators takes account of the heterogenity of innovative firms with respect to size, age, industry and products. In order to separate very successful from less successful business, all firms were ranked according to each of the above indicators. A separation into the two groups was reached by applying five different combinations of indicators (the following combinations are chosen: all indicators; $1,2,3,4,9 ; 1,2,3,7,8,10 ; 1,2,3$, $5,7,8,10 ; 1,2,3,4,7,8)$ to the whole sample. Those 16 firms who ranked for all five combinations on top of the list were attributed to the group of very successful new businesses whereas those who ranked for all five combinations of indicators at the end of the list formed the group of 18 less successful new businesses. The middle group of 16 businesses was not included when we wished to determine whether there were differences between less successful and very successful innovative start-ups.

\section{Results}

The following presentation of the empirical results offers interesting insights on the innovative idea, the entrepreneurial activities, and different forms of organizing innovativ start-ups in relation to the market context.

\subsection{Innovative entrepreneurial ideas}

Founders were asked for the benefits generated by their products. Such benefits can be assessed in terms of general advantages associated with the use of the product (rating of items in a list of advantages such as saving of time; effectiveness; gain in prestige; quality; flexibility; reduced search, coordination, execution and monitoring activities; facilitation of new services or products). On the other hand, one can ask for the relevance of specific cost advantages that are associated with the use of the product. For this purpose a long list of cost categories was presented to the entrepreneur who in turn rated each category. Table 3 presents mean values of the perceived product advantages as well as their correlations with the specific cost advantages.

A rating of at least four to five points can be interpreted as an indicator for an important product benefit. Thus, increase of quality, effectiveness, increase of flexibility, faciliation of a new good or service, saving of time, reduced monitoring, search, and execution activities can be seen as the leading arguments for the new businesses in this sample. Increased flexibility, reduction in monitoring activities, search activities and execution activities can be directly associated with transaction costs. Thus, not only direct production cost but also transaction cost arguments play a major role in evaluating new entrepreneurial ideas.

Table 3 contains only those cost categories that were rated at least on an average level of four or higher. Those meaningful cost categories are corre- 
lated with the product advantages in the way represented in Table 3 . The highly significant results of this correlation analysis underline the differing importance of production and transaction costs for product advantages. Increase in flexibility, for instance, is highly correlated with typical kinds of transaction costs, such as costs of monitoring, communication costs, information costs,

Table 3

Correlation analysis of product and cost advantages of innovative ideas

\begin{tabular}{|c|c|c|c|}
\hline Product advantages & Cost advantages & $\begin{array}{l}\text { Level of } \\
\text { signifi- } \\
\text { cance }\end{array}$ & $\begin{array}{l}\text { Correlation } \\
\text { coefficient }\end{array}$ \\
\hline $\begin{array}{l}\text { Timesavings } \\
(m=5.11)\end{array}$ & Training costs & 0.007 & 0.3393 \\
\hline $\begin{array}{l}\text { Effectiveness } \\
(m=5.59)\end{array}$ & Personnel costs & 0.000 & 0.5084 \\
\hline $\begin{array}{l}\text { Gain in prestige } \\
(m=3.28)\end{array}$ & $\begin{array}{l}\text { Consultancy costs } \\
\text { Rental of premises }\end{array}$ & $\begin{array}{l}0.007 \\
0.003\end{array}$ & $\begin{array}{l}0.3375 \\
0.3826\end{array}$ \\
\hline $\begin{array}{l}\text { Quality } \\
\text { improvement } \\
(m=5.90)\end{array}$ & $R \& D$ costs & 0.002 & 0.3948 \\
\hline $\begin{array}{l}\text { Increased } \\
\text { flexibility } \\
(m=5.50)\end{array}$ & $\begin{array}{l}\text { Information costs } \\
\text { Control costs } \\
\text { Organization costs } \\
\text { Data processing costs } \\
\text { Communication costs } \\
\text { Training costs }\end{array}$ & $\begin{array}{l}0.004 \\
0.008 \\
0.001 \\
0.006 \\
0.004 \\
0.002\end{array}$ & $\begin{array}{l}0.3632 \\
0.3343 \\
0.4178 \\
0.3452 \\
0.3590 \\
0.3871\end{array}$ \\
\hline $\begin{array}{l}\text { Reduction of } \\
\text { search activities } \\
(m=4.65)\end{array}$ & Information costs & 0.000 & 0.5880 \\
\hline $\begin{array}{l}\text { Coordination } \\
\text { activities } \\
(m=3.57)\end{array}$ & $\begin{array}{l}\text { Distribution costs } \\
\text { Transport costs } \\
\text { Organization costs } \\
\text { Information transfer } \\
\text { costs } \\
\text { Data processing costs } \\
\text { Information storage } \\
\text { costs }\end{array}$ & $\begin{array}{l}0.001 \\
0.001 \\
0.005 \\
0.002 \\
0.001 \\
0.005\end{array}$ & $\begin{array}{l}0.4183 \\
0.4143 \\
0.3526 \\
0.4022 \\
\\
0.4421 \\
0.3513\end{array}$ \\
\hline $\begin{array}{l}\text { Execution } \\
\text { activities } \\
(m=4.23)\end{array}$ & $\begin{array}{l}\text { Organization costs } \\
\text { Data processing costs }\end{array}$ & $\begin{array}{l}0.004 \\
0.004\end{array}$ & $\begin{array}{l}0.3635 \\
0.3625\end{array}$ \\
\hline $\begin{array}{l}\text { Monitoring } \\
\text { activities } \\
(m=5.09)\end{array}$ & $\begin{array}{l}\text { Personnel costs } \\
\text { Testing and measure- } \\
\text { ment costs }\end{array}$ & $\begin{array}{l}0.004 \\
0.003 \\
0.002 \\
0.002\end{array}$ & $\begin{array}{l}0.3614 \\
0.3757 \\
0.4011 \\
0.4027\end{array}$ \\
\hline $\begin{array}{l}\text { Facilitation of a } \\
\text { new type of ser- } \\
\text { vice or product } \\
(m=5.23)\end{array}$ & Travel costs & 0.009 & $\begin{array}{l}-0.3269 \\
-0.3884\end{array}$ \\
\hline \multicolumn{4}{|c|}{$\begin{array}{l}\text { Variable product advantages }=10 \text { characteristics. } \\
\text { Variable cost advantages }=27 \text { characteristics. } \\
n_{\text {Tot }}=52 .\end{array}$} \\
\hline
\end{tabular}


Table 4

Cost advantages: Transaction costs and production costs

\begin{tabular}{|c|c|c|}
\hline $\begin{array}{l}\text { Factor } 1 \\
\text { External trans- } \\
\text { action costs }\end{array}$ & $\begin{array}{l}\text { Factor } 2 \\
\text { Internal trans- } \\
\text { action cosis }\end{array}$ & $\begin{array}{l}\text { Factor } 3 \\
\text { Classical pro- } \\
\text { duction costs }\end{array}$ \\
\hline $\begin{array}{l}\text { Consultancy costs } \\
\text { Marketing costs } \\
\text { Market development } \\
\text { costs } \\
\text { Travel costs } \\
\text { Administration costs } \\
\text { Communication costs } \\
\text { Storage costs }\end{array}$ & $\begin{array}{l}\text { Data processing } \\
\text { costs } \\
\text { Information storage } \\
\text { costs } \\
\text { Information transfer } \\
\text { costs } \\
\text { Organization costs } \\
\text { Control costs } \\
\text { Information costs }\end{array}$ & $\begin{array}{l}\text { Production costs } \\
\text { Cost of materials } \\
\text { R\&D costs } \\
\text { Construction } \\
\text { costs } \\
\text { Testing and } \\
\text { measurement } \\
\text { costs }\end{array}$ \\
\hline $\begin{array}{l}\text { Factor } 4 \\
\text { Service costs }\end{array}$ & $\begin{array}{l}\text { Factor } 5 \\
\text { Logistic costs }\end{array}$ & $\begin{array}{l}\text { Factor } 6 \\
\text { Personnel costs }\end{array}$ \\
\hline $\begin{array}{l}\text { Service costs } \\
\text { Repair costs } \\
\text { Training costs }\end{array}$ & $\begin{array}{l}\text { Energy costs } \\
\text { Transport costs } \\
\text { Distribution costs } \\
\text { Rental of premises }\end{array}$ & Personnel costs \\
\hline $\begin{array}{l}n_{\text {Tot. }}=52 . \\
\text { Factor analysis accord } \\
6 \text { Factors, standardize } \\
\text { Varimax-rotation. }\end{array}$ & $\begin{array}{l}\text { to SPSS-Standar } \\
\text { Eigenvalue: } 0.001 \text {, }\end{array}$ & Analysis; \\
\hline
\end{tabular}

etc. The same is true for the other transaction cost-oriented product advantages. Thus, the analysis shows that not only direct production costs but also transaction cost factors are very important for the assessment of new entrepreneurial ideas.

With help of a factor analysis (with six factors), we tried to find out whether transaction costs could represent distinct cost categories within the cost-oriented thinking of innovative entrepreneurs. Table 4 shows the result of this analysis.

Factors 1 and 2 clearly relate to transaction cost considerations whereas Factors 3 and 6 are mainly related with classical production costs. Factors 4 and 5 seem to be somewhat of a mix between transaction costs and production costs. This kind of cost analysis helps to broaden the conception of costs (and benefits) which is useful for the evaluation of entrepreneurial ideas. Arguments that so far could only be intuitively perceived as economic advantages can be seen as transaction cost advantages.

Interestingly enough the analysis of product advantages and cost advantages did not differ between very successful and less successful new firms. This shows that transaction cost considerations are to a similar degree present in all innovative entrepreneurial ideas within this sample of existing new businesses.

However, with respect to other aspects of the innovative entrepreneurial idea, results do differ according to the degree of success of the enterprise. Very successful enterprises for instance used twice as many measures to protect their ideas (patents, internal precautions, etc.) than the less successful group. Also very successful new businesses pursued ideas whose degree of innovativeness was a little less than in the group of the less successful firms. This could mean that too high a degree of innovation does not guarantee market success.

\subsection{Entrepreneurial abilities and functions}

As could be seen in the sample structure (Table 2 ), the education of new entrepreneurs is mainly oriented towards science and technology. A market and business orientation is less developed. In the same way the experience in trade can influence the

Table 5

Entrepreneurial abilities of the innovative founders

\begin{tabular}{|c|c|c|c|c|c|c|c|}
\hline & \multirow[t]{2}{*}{ Abs. } & \multirow[t]{2}{*}{ Rel. (\%) } & \multicolumn{2}{|c|}{$\begin{array}{l}\text { Less successful } \\
\text { enterprise }\end{array}$} & \multicolumn{2}{|c|}{$\begin{array}{l}\text { Very successful } \\
\text { enterprise }\end{array}$} & \multirow[t]{2}{*}{ Significance } \\
\hline & & & $\overline{\text { Abs. }}$ & Rel.(\%) & Abs. & $\operatorname{Rel.(\mathscr {O})}$ & \\
\hline Idea generation & 43 & 87.7 & 14 & 79.8 & 12 & 75.6 & 0.855 \\
\hline Organization & 20 & 38.5 & 9 & 52.3 & 7 & 44.1 & 0.725 \\
\hline Marketing & 31 & 59.6 & 5 & 27.8 & 13 & 81.3 & 0.001 \\
\hline Total (multiple replies) & $\overline{94}$ & $\overline{180.8}$ & $\overline{28}$ & $\overline{159.9}$ & $\overline{32}$ & $\overline{201.0}$ & \\
\hline$n_{\text {Tot }}=52$ & ssfu & ises $n=$ & suc & nterpr & 16. & & \\
\hline
\end{tabular}


success of innovative start-ups; $75 \%$ of the founders of very successful start-ups had trade experience in companies to $50 \%$ of the less successful founders. This can turn out to be a problem for the realization of a successful start-up.

In a further step entrepreneurs were asked for their specific entrepreneurial abilities (Table 5). 43 saw their main strength in the domain of idea generation, 20 in the area of organization and 31 in the field of marketing (multiple replies). This shows relatively low concern for markets and organization. When looking at the two success groups the consequences of this finding become obvious: 14 of the 18 less successful new firms saw their special strength in the field of idea generation, 9 in the area of organization and only 5 in marketing; of 16 very successful foundations, 12 perceived themselves to be strong in idea generation, 7 in the area of organization and 13 in marketing (multiple replies). This shows already that those entrepreneurs who are strong in idea generation and in marketing seem to be more successful than those who are only inventors.

A closer look at the team structure of the start-ups confirmed this picture (Table 6).

Whereas among the very successful firms a team of founders dominates, the reverse is true for the less successful firms. Teams seem to cover more entrepreneurial abilities than singles. However, one has to combine the argument of team with the argument of range of entrepreneurial functions in order to come up with a convincing analysis. This is done in Table 7.

Portfolio 1 means that the one single or the team founders represent only one of the three entrepreneurial functions needed, value 2 indicates that 2 of the 3 entrepreneurial functions are fulfilled, with the value 3 all 3 entrepreneurial

Table 6

Success-oriented comparison of team set-ups with set-ups by an individual

\begin{tabular}{llcll}
\hline & Team set-up & \multicolumn{3}{l}{$\begin{array}{l}\text { Set-up by an } \\
\text { individual }\end{array}$} \\
\hline Very successful & 10 & 6 & $:$ & 16 \\
Less successful & $\frac{7}{17}$ & $\frac{11}{17}$ & $:$ & $\frac{18}{34}$
\end{tabular}

Very successful $n=16$.

Less successful $n=18$.
Table 7

Entrepreneurial functions portfolio, number of founders and success of start-ups

\begin{tabular}{|c|c|c|c|c|c|c|c|c|}
\hline \multirow{3}{*}{$\begin{array}{l}\text { No. of } \\
\text { founders }\end{array}$} & \multicolumn{8}{|c|}{ Range of functions } \\
\hline & \multicolumn{2}{|l|}{$\overline{1}$} & \multicolumn{2}{|l|}{2} & \multicolumn{2}{|l|}{3} & \multirow{2}{*}{\multicolumn{2}{|c|}{$\begin{array}{l}a \\
b\end{array}$}} \\
\hline & $\bar{a}$ & $b$ & $\bar{a}$ & $\mathrm{~b}$ & $\bar{a}$ & 5 & & \\
\hline 1 & 6 & 0 & 4 & 3 & 1 & 3 & 17 & $\begin{array}{l}65 \% \\
35 \%\end{array}$ \\
\hline 2 & 1 & 0 & 0 & 1 & 2 & 2 & 6 & $\begin{array}{l}50 \% \\
50 \%\end{array}$ \\
\hline $\begin{array}{l}3 \\
\text { and more }\end{array}$ & 2 & 1 & 1 & 3 & 1 & 3 & 11 & $\begin{array}{l}36 \% \\
64 \%\end{array}$ \\
\hline & $\begin{array}{c}9 \\
90 \%\end{array}$ & $\begin{array}{c}1 \\
10 \%\end{array}$ & $\begin{array}{c}5 \\
42 \%\end{array}$ & $\begin{array}{c}7 \\
58 \%\end{array}$ & $\begin{array}{c}4 \\
33 \%\end{array}$ & $\begin{array}{c}8 \\
67 \%\end{array}$ & 34 & \\
\hline $\begin{array}{l}n_{\text {Tot. }}=52 . \\
a^{2}=\text { Less } s t \\
b=\text { Very st }\end{array}$ & $\begin{array}{l}\text { ccessf } \\
\text { ccess }\end{array}$ & $\begin{array}{l}\text { set-1 } \\
\text { set- }\end{array}$ & $\begin{array}{l}\text { s }(n \\
\text { s }(n\end{array}$ & $\begin{array}{l}=18) . \\
=16) \text {. }\end{array}$ & & & & \\
\hline Range of & bilitie & $\begin{aligned}= & V a \\
& \text { fou }\end{aligned}$ & $\begin{array}{l}\text { abilit } \\
\text { ader } 0\end{array}$ & $\begin{array}{l}\text { of en } \\
\text { set-u }\end{array}$ & $\begin{array}{l}\text { reprer } \\
\text { team }\end{array}$ & $\begin{array}{l}\text { eurial } \\
\text { respec }\end{array}$ & $\begin{array}{l}\text { abilit } \\
\text { tivel }\end{array}$ & ies of a \\
\hline
\end{tabular}

abilities are present. Table 7 provides the following conclusion: for a one person foundation it is advisable to cover all three entrepreneurial functions. On the other hand it seems also advisable to increase the number of founders in order to obtain more functions. The best way is to combine the team with a broad portfolio of entrepreneurial abilities. This allows for complementarity in management and, thereby, for success with the new enterprise.

\subsection{Organization of the new firm}

A very important decision of an innovative entrepreneur concerns the question what components and other intermediate goods and services he or she should buy from the market and what components etc. should be produced within the firm.

Looking at the two success groups of the sample, interesting trends can be detected. Whereas very successful new firms tend to switch from internally-made components to market-supplied components as soon as conditions are favorable, less successful firms tend to do the reverse. Figure 2 underlines this finding; correlation coefficients may here be interpreted in terms of flexibility of 


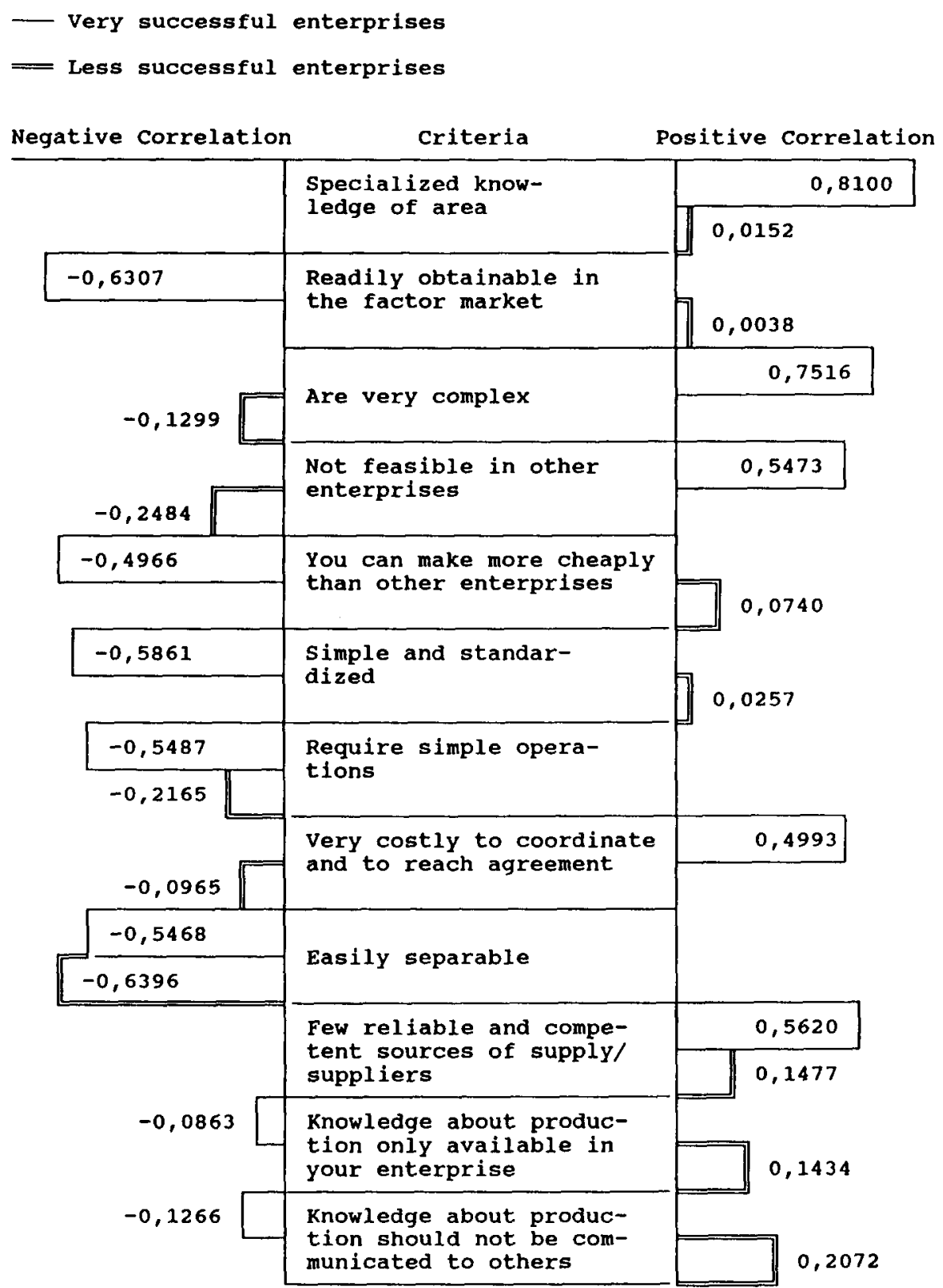

Figure 2. Determinants of the intended policy to produce internally by very successful and less successful enterprises

future make-policy with respect to the corresponding criteria.

Future intended make-policy of very successful firms correlates much higher with the listed criteria than on the other side of less successful companies. Very successful innovative start-ups seem to react much more sensitively (and in the manner predicted by transaction cost theory) to changing conditions of markets and product characteristics - this seems to be a conspicuous property of transaction cost minimizing entrepreneurship in a dynamic world.

So far we have only looked at two extreme forms of organization (make-or-buy). We now want to investigate a little bit more closely the manifold world of contracts which governs the relations with external suppliers. Two main characteristics of input resources involved are distinguished: standardized goods and specific goods. Transaction cost theory attributes a very high 
Table 8

Comparison of contractual forms for standardized and specific intermediate goods

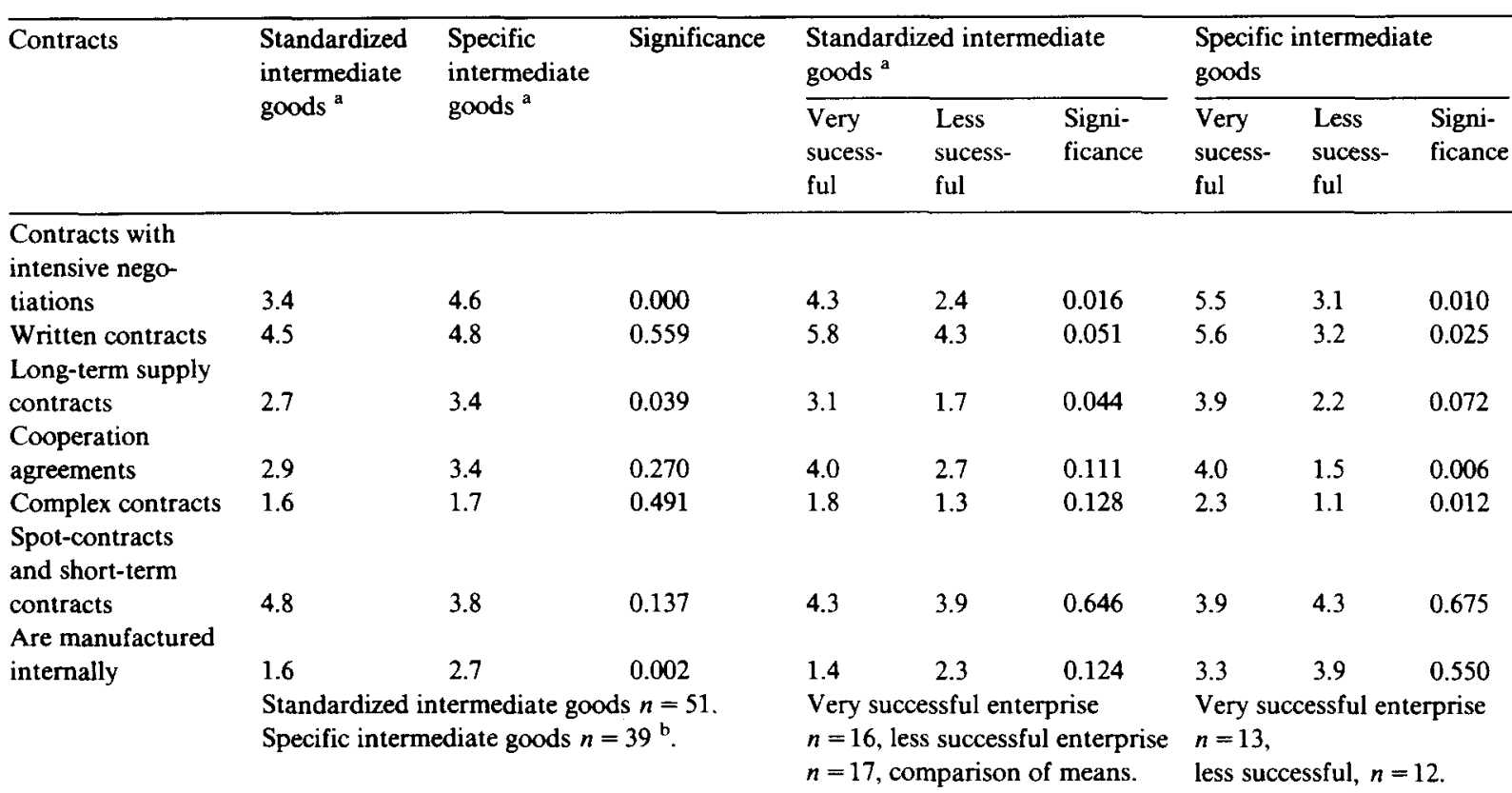

a Mean averages of each statement, $1=$ not accurate, $7=$ fully accurate.

b The divergence of the original sample $(52,18$ or 16$)$ results from the fact that some firms produce all their components internally.

theoretical importance to this distinction, in order to explain the emergence and the selection of efficient forms of contracts (for the influence of specificity on coordination modes, see Klein, Crawford and Alchian, 1978; Williamson, 1979; Picot, 1982. p.276ff.; Alchian, 1984; Williamson, 1985, pp.52-56). Specific goods have a much higher value in the special application of the buyer than in alternative uses when sold on the market.
This specifity gives rise to information and communication problems as transactors attempt to reach a mutual agreement. Transaction-specific investments of human capital, machines and material have to be protected from opportunistic behavior of the other partner. Thus, an interest of long-term agreement and mutual commitment is generated and results in a higher degree of vertical integration. On the other hand, standardized in-

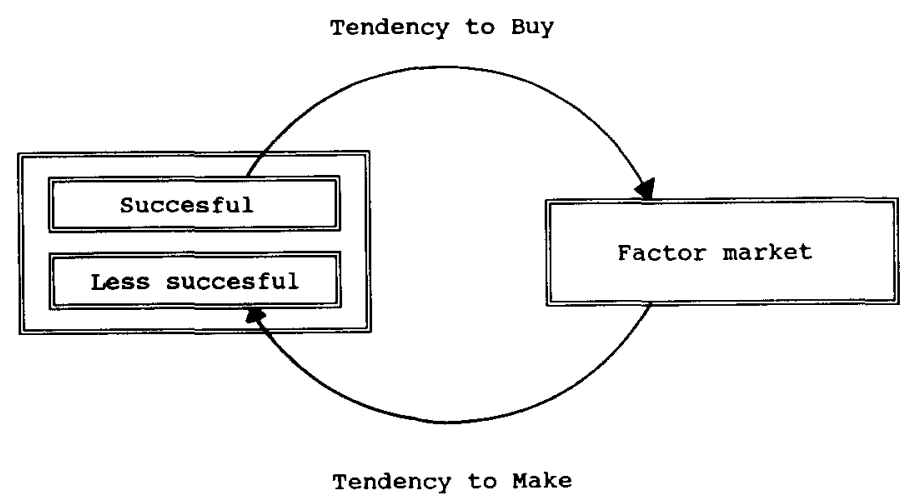

Figure 3. Success-oriented analysis of make-or-buy tendencies 
Table 9

Organization of sales and marketing

\begin{tabular}{|c|c|c|}
\hline Organization of marketing by & $\begin{array}{l}\text { Very success- } \\
\text { ful Enterprises }\end{array}$ & $\begin{array}{l}\text { Less success- } \\
\text { ful Enterprises }\end{array}$ \\
\hline Specialized journals and fairs & 0 & 3 \\
\hline Founder and internal employees & 3 & 8 \\
\hline External sales agents/corporations & 3 & 0 \\
\hline Internal und external marketing agents/corporations & $\underline{10}$ & 7 \\
\hline Total & 16 & 18 \\
\hline Very successful enterprises: $n=16$ & \multicolumn{2}{|c|}{ Less successful enterprises: $n=18$. } \\
\hline
\end{tabular}

puts are highly mobile in markets. There is no need for protection of transaction-specific investments. Therefore the degree of vertical integration can be low.

The modes of contracting show different structures between very successful and less successful innovative start-ups (see Table 8).

Examples of specific intermediate goods are special designs and plans. Examples of standardized intermediate goods are uniform components which are also used by other firms and in other products.

Comparison between specific and standardized input factors shows that specific inputs:

- are more intensively negotiated,

- are governed by longer-term contracts, whereas standardized products are obtained more on the spot-market basis,

- are much more often made internally.

Looking at the two success groups of the sample one can easily realize that very successful new firms show all in all a much higher level of contracting than the less successful firms. This is true for specific inputs as well as for standardized ones.
Contracts involving intensive negotiations, written contracts, long-term contracts and cooperation agreements are utilized more extensively by very successful innovative enterprises than by less successful enterprises. It must also be noted that less successful new innovative firms tend to produce standardized inputs themselves to a higher degree than very successful firms. This confirms the tendency shown in Figure 2 that very successful firms tend to exhaust economic possibilities of buying in markets.

The results shown in this and in the previous section indicate that very successful business startups adopt an extrovert management policy for coordination of input resources whereas less successful new firms apply an introvert policy. This assessment relates to make-or-buy decisions, as well as to the level of contracting for externally procured resources (see Figure 3).

The effect of the two policies is that the very successful firms can concentrate much more on their innovative core activities and at the same time are able to govern external relations to a more efficient degree. Probably the more extensive range of entrepreneurial functions, which includes

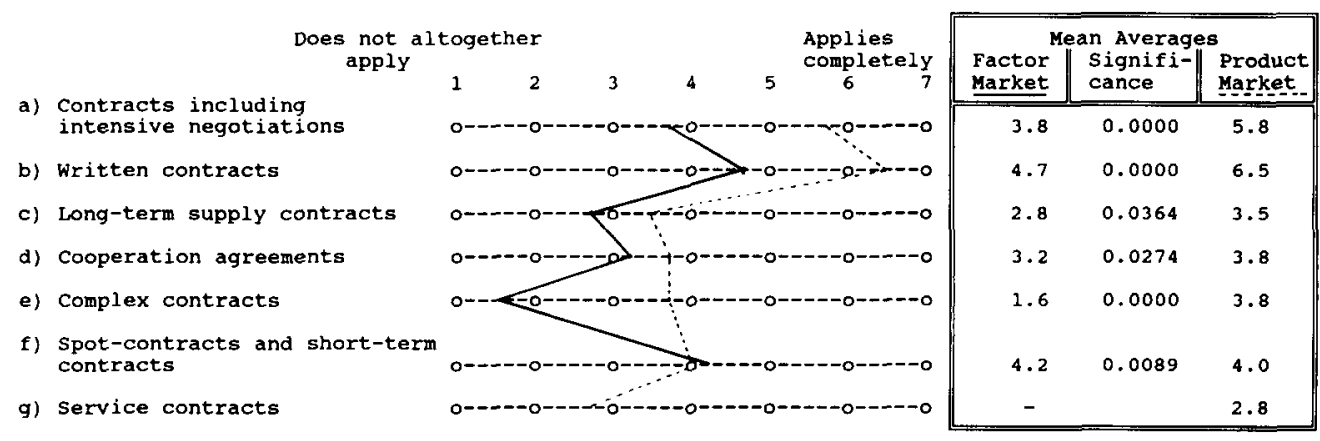

Figure 4. Comparison of contract structures in factor and product markets 
also organizational and market-oriented abilities is partly responsible for this superiority.

Successful operations of new firms must be supported by efficient organizational structures of the marketing channels in order to reach potential buyers of the product. Table 9 shows the four different forms of marketing organization used by the innovators.

It is noticeable that very successful new firms again are much more oriented towards the external world with their organization of sales agents and they do not mainly rely on traditional channels (specialized journals, fairs) and on the internal competence of the founder and his employees, as it is the case with less successful start-ups. Transaction costs of marketing and distribution can be more efficiently exhausted.

Contracting modes used by new innovative firms in sales operations are shown in Figure 4 related to the contractual nature of resource coordination.

It should be noticed that contract structures in sales are on average of a higher level and more integrated than those of the input side. This is an indicator of the relative novelty and specifity of the product offered by those firms. In many cases first-mover situations as well as small-number situations should prevail. Therefore more intensive negotiations as well as long-term oriented contracting is advisable. With respect to the two success groups no significant differences in sales contracting could be detected. There was a slight tendency for very successful new firms to adopt a higher level of integration with their customers.

\section{Conclusion}

The empirical results of the present study underline the relevance of transaction cost factors for a success-oriented analysis of innovative startups. Transaction costs not only influence the viability of innovative ideas but also give valuable advice for the design of the organization of a new innovative firm.

The success of innovative ideas depends on the realization of transaction cost advantages as well as on production cost advantages. The organization of market relations differs more significantly between very successful and less successful new entrepreneurs than do the results for the innovative idea.

Therefore, one can assume that the majority of the investigated firms pursue an essentially viable new idea but at the same time, many firms have some difficulty in efficiently organizing their market relations and their internal organization. To the extent that innovative founders are not able to organize transaction cost-efficient supply relations in the market, they are forced to switch to internal production. This tendency was traceable for the group of less successful innovative firms. Very successful new firms, on the other hand, delegate their coordination problems to the highest efficient degree to the market. Their comparatively high level of contracting ensures, at the same time, a higher degree of integration of their external suppliers.

Design and development of transaction cost-efficient coordination modes seem to be a very important property of innovative entrepreneurs in a dynamic environment. Compared with less successful founders, the very successful new entrepreneurs showed a higher flexibility of coordination modes with respect to changes of characteristics of products and markets. Their flexibility takes the direction predicted by transaction cost theory, i.e. they switch to external procurement in markets whenever possible. Less successful firms are more rigid in their procurement policy. It would be advisable that founders, as well as consultants and other supporting institutions develop a higher sensitivity for this issue.

Heterogenous teams of founders with experience in the industry, market knowledge, as well as an education in business administration are much more successful than those who mainly rely on an education in science and technology. One could suspect that this factor influences the preceding conclusions on successful internal and external organization of production and marketing.

This investigation also leads to the conclusion that the application of new institutional economics (in particular, transaction cost theory, property rights and contract theory, neo-Austrianism) combined with organization and diffusion theory can be fruitful for further research on innovation and on the determinants of a successful realization of innovative start-ups. 


\section{Acknowledgement}

This paper was presented to EURO-TIMS IV Conference in July 6-8, 1988, in Paris.

This research was supported by a grant from the German Science Foundation (DFG) for a larger project of which the present research is one part. The authors thank David Harper for his helpful comments on the English version of this paper. The final report of the larger project is published as Picot, Laub and Schneider (1989); for detailed and further results concerning this research project see Laub (1989), Schneider (1988).

\section{References}

Alchian, A.A. (1984), "Specifity, specialization, and coalitions", Journal of Theoretical and Institutional Economics 40, 34-49.

Casson, M. (1982), The Entrepreneur - An Economic Theory, Basil Blackwell, Oxford.

Coase, R.H. (1937), "The nature of the firm", Economica 4, $386-405$.

Kirzner, I.M. (1973), Competition and Entrepreneurship, University of Chicago Press, Chicago, IL.

Klein, B., Crawford, R.G., and Alchian, A.A. (1978), "Vertical integration, appropriable rents, and the competitive contracting process", The Journal of Law and Economics 21, 297-326.

Laub, U.D. (1989), Zur Bewertung innovativer Unternehmensgriüdungen im institutionellen Zusammenhang - Eine empirisch gestützte Analyse, VVF, München.

Picot, A. (1982), "Transaktionskostenansatz in der Organisationstheorie: Stand der Diskussion und Aussagewert", Die Betriebswirtschaft 42, 267-284.
Picot, A., and Schneider, D. (1988), "Unternehmerisches Innovationsverhalten, Verfügungsrechte und Transaktionskosten", in: D. Budäus, E. Gerum and G. Zimmermann (eds.), Betriebswirtschaftslehre und Theorie der Verfügungsrechte, Gabler, Wiesbaden, 18-38.

Picot, A., Laub, U.D., and Schneider, D. (1989), Innovative Unternehmensgrïndungen - Eine ökonomische Analyse, Springer-Verlag, Berlin.

Reekie, D. (1984), Markets, Entrepreneurs and Liberty: An Austrian View of Capitalism, Harvester Press, Brighton.

Ricketts, M. (1987), The Economics of Business Enterprise New Approaches to the Firm, Harvester Press, Brighton.

Rogers, E.M. (1983), Diffusion of Innovations, Free Press, New York.

Sandberg, W.R. (1986), New Venture Performance, Lexington Books, Toronto, MA.

Schneider, D. (1988), Zur Entstehung innovativer Unternehmen - Eine ökonomisch-theoretische Perspektive, VVF, München.

Thom, N. (1980), Grundlagen des betrieblichen Innovationsmanagements (2nd edition), Hanstein, Königstein/Taunus.

Ven, A.H. Van de (1986), "Central problems in the management of innovation", Management Science 32, 590-607.

Wegehenkel, L. (1981), Gleichgewicht, Transaktionskosten und Evolution, Mohr, Tübingen.

Williamson, O.E. (1975), Markets and Hierarchies - Analysis and Antitrust Implications, The Free Press, Collier Macmillan, London.

Williamson, O.E. (1979), "Transaction-cost economics: The governance of contractual relations", Journal of Law and Economics 22, 3-61.

Williamson, O.E. (1985), The Economic Institutions of Capitalism - Firms, Markets Relational Contracting, The Free Press, Collier Macmillan, London.

Williamson, O.E. (1986), Economic Organization - Firms, Markets and Policy Control, Wheatsheaf Books, Brighton.

Witt, U. (1987), "How transaction rights are shaped to channel innovativeness", Journal of Institutional and Theoretical Economics 143, 180-195. 